\title{
Macrophyte and macroinvertebrate patterns in unimpacted mountain rivers of two European ecoregions
}

\author{
Krzysztof Szoszkiewicz • Szymon Jusik • Iga Lewin • Izabela Czerniawska-Kusza • \\ Jerzy Mirosław Kupiec • Marta Szostak
}

Received: 2 November 2016/Revised: 2 October 2017/Accepted: 2 November 2017/Published online: 14 November 2017

(C) The Author(s) 2017. This article is an open access publication

\begin{abstract}
The aim of the study was to compare the patterns of development of macrophytes and macroinvertebrates in different types of reference mountain rivers. The study is based on reference river sites surveyed throughout the mountains in Poland and Slovakia in two European ecoregions (9-Central Highlands, 10-The Carpathians). A wide range of environmental variables were estimated, including water chemistry, hydromorphology, geology, and the spatial factor. Based on the Jaccard index, macrophyte
\end{abstract}

Handling editor: Marcello Moretti

Electronic supplementary material The online version of this article (https://doi.org/10.1007/s10750-017-3435-5) contains supplementary material, which is available to authorised users.

K. Szoszkiewicz $\cdot$ S. Jusik $(\bowtie) \cdot J$. M. Kupiec

M. Szostak

Department of Ecology and Environmental Protection,

Faculty of Environmental Engineering and Spatial

Management, Poznan University of Life Sciences,

Poznan, Poland

e-mail: jusz@up.poznan.pl

I. Lewin · M. Szostak

Department of Hydrobiology, Faculty of Biology and Environmental Protection, University of Silesia,

Katowice, Poland

I. Czerniawska-Kusza $\cdot$ M. Szostak

Department of Land Protection, University of Opole,

Opole, Poland and macroinvertebrate variation was confirmed between four mountain and upland river types. It was found that the biological diversification is mainly influenced by geological and associated chemical factors. In the case of macroinvertebrates, additionally, the importance of the spatial factor was revealed (difference between ecoregions). Finally, the habitat preferences of various taxa were identified. It was found that extreme mountain conditions can sometimes distort bioindicative response, as was detected in the case of macroinvertebrates in the highest mountain sites. We concluded that consideration of two groups of organisms enables more comprehensive and reliable monitoring than assessment based on a single group, especially when standard bioindicative methods can be distorted by extreme local conditions.

Keywords Reference rivers - Macroinvertebrates · Macrophytes $\cdot$ Mountains $\cdot$ River assessment

\section{Introduction}

Freshwater reference conditions represent a pristine state or nearly pristine examples of certain types of aquatic ecosystems in the absence of human disturbance or alteration (Stoddard et al., 2006). In the case of rivers, such conditions are very rare today, due to the scale of river degradation in the biosphere (Moss, 2008; Demars et al., 2012). Human impact causes a 
variety of problems leading to the deterioration of river habitats, one of the most serious include eutrophication, acidification, and changes in hydrology and river morphology (Malmqvist \& Rundle, 2002; Johnson \& Hering, 2009; Manfrin et al., 2013). Moreover, several groups of aquatic organisms suffer markedly from impoundments and losses of river integrity (Marzin et al., 2012).

The identification of biological attributes developing under reference conditions in rivers and lakes has become an important issue recently due to the development of the ecological classification in water monitoring introduced in the EU by the Water Framework Directive (WFD) (European Commission, 2000). The WFD introduced a new approach to the assessment and classification of surface waters, which is based on biological components such as phytobenthos, macrophytes, phytoplankton, benthic macroinvertebrates and fish. The ecological status of a water body is defined as the deviation between the organisms identified there and the biological communities detected under reference conditions. Therefore, precise and efficient monitoring requires the correct identification of biological communities in reference conditions for each existing river type (Moss, 2008; Nõges et al., 2009; Demars et al., 2012; Mao \& Richards, 2012). Ecological assessment based on reference conditions is used to measure streams' health, to identify degraded conditions and to monitor human impact or determine restoration effectiveness; it is also applied outside the European Union member states (Pond, 2012; Gerth et al., 2013; Kosnicki et al., 2014). Unfortunately, biological recognition of pristine rivers is not sufficient especially in mountains. Most of studies on reference sites are usually limited to a single organism group and covered mostly lowland streams. The combined macrophyte and macroinvertebrate studies in highland streams were carried out to some extent by other authors (e.g. Pinto et al., 2006; Hering et al., 2006; Thiébaut et al., 2006; Traversetti et al., 2014, 2015) but their studies did not focus on unimpacted river sites. Hughes et al. (2009), Błachuta et al. (2014) and Lainé et al. (2014) also surveyed macroinvertebrates as well as macrophytes, but those studies were limited to lowland rivers, and reference sites were not included.

In Central Europe, we can still find relatively abundant high-quality river ecosystems that remain unaltered by human activity where natural processes still operate on a large scale (Krno et al., 2007; Šporka et al., 2009; Szoszkiewicz et al., 2010a; Wyżga et al., 2012; Mazur et al., 2016). Due to the high ecological quality of some rivers in Poland, they are often used for international comparisons (Dynesius \& Nilsson, 1994; Antheunisse et al., 2006; Baattrup-Pedersen et al., 2006; Birk \& Willby, 2010) and even used as a reference for other countries (Baattrup-Pedersen et al., 2008). The ecological quality of reference rivers in Poland is particularly high in the mountains, because processes of channel modification have never been implemented on an extensive scale in these areas. Moreover, pastoral and agricultural activities on hill slopes considerably decreased in many mountain regions during the twentieth century, limiting the human impact on the river network (Wyżga et al., 2012). In addition, well-preserved stretches of mountain rivers in Poland have survived as a result of nature conservation efforts-all major mountains in Poland are protected very effectively by various forms of conservation institutions, including nine mountainous National Parks (Zawilińska \& Mika, 2013).

The results of the present study were obtained within a large scientific project where large number of sites is located on pristine mountain and upland rivers in two European ecoregions in the area of Poland and Slovakia. The aim of the study was to identify the habitat differentiation between various stream types by analysing numerous chemical, hydromorphological, geological and spatial factors of unimpacted river sites. Moreover, we focused on development of two important groups of organisms for biomonitoring as macrophytes and macroinvertebrates, and we tried to detect their differentiation between various river types. We anticipate that macrophytes and benthic macroinvertebrates are diversified by river-type-specific environmental factors. We hypothesise that biological differentiation reflects the existing typological pattern of mountain and highland rivers. Moreover, we hypothesise that macrophytes and macroinvertebrates respond differently in species composition and their diversity to various environmental factors. The applied aim of our study was to show that the consideration of two groups of organisms in biomonitoring delivers more comprehensive and reliable information than assessment based on a single group. 


\section{Methods}

\section{Environmental surveys}

A comprehensive description of the abiotic conditions was completed for each of the selected survey sites. It included altitude, slope, valley geology, width and depth of the riverbed, hydromorphological quality, as well as physical and chemical water measurements.

The hydromorphological evaluation was conducted according to the River Habitat Survey (RHS) method (Raven et al., 1998). Data collection in the RHS system is based on standard $500 \mathrm{~m}$ stretches of rivers, where features of the channel and adjacent valley are recorded. Based on the RHS protocol, several numerical metrics were calculated, beginning with the two principal RHS metrics (Raven et al., 1998): Habitat Quality Assessment (HQA) and Habitat Modification Score (HMS). Low values of the HMS indicate limited artificial modification of watercourses, whereas higher values indicate a high habitat modification. High values of the HQA indicate the extensive presence of a number of natural river features. Furthermore, the RHS protocol made it possible to calculate the granulometry index $\left(\mathrm{GM}_{\text {index }}\right.$; Jusik et al., 2015) reflecting the average grain size composition of the riverbed material, and the flow dynamics index (FT index; Jusik et al., 2015) which aggregates the energy of the flowing water as an average of flow types present in the $500 \mathrm{~m}$ length of surveyed channel.

Water samples were collected in the middle of the stream from each survey site immediately prior to biological sampling. Overall, nine physical and chemical parameters were determined. Electrical conductivity and $\mathrm{pH}$ were obtained from portable digital potentiometers, and the concentration of dissolved oxygen was measured by a digital oximeter. Alkalinity and total hardness were measured by potentiometric methods-alkalinity by titrating with sulphuric acid to an end point of $\mathrm{pH} 4.5$ in the presence of methyl orange, and total hardness by titrating with disodium edetate. Concentrations of phosphate (molybdenum blue method), nitrate nitrogen (cadmium reduction method) and ammonium nitrogen (Nessler's method) were determined using a spectrophotometer.
Biological surveys

Macrophytes were surveyed during the summer seasons of 2009-2013, between mid-June and the end of July. The field procedure followed the official Polish monitoring protocol, which is based on the Macrophyte Index for Rivers (MIR) (Szoszkiewicz et al., 2010b). Aquatic plants were surveyed along river stretches $100 \mathrm{~m}$ in length. Only river macrophytes growing in the water (at least rooted in the water) were recorded. The macrophyte identified to the level of species (macroalgae-genera). The presence of each taxa was recorded with its percentage cover using the following nine-point scale: 1 for $<0.1 \%, 2$ for $0.1-1 \%, 3$ for $1-2.5 \%, 4$ for $2.5-5 \%, 5$ for $5-10 \%, 6$ for $10-25 \%, 7$ for $25-50 \%, 8$ for $50-75 \%$ and 9 for $>75 \%$. Based on gathered field records, several macrophyte metrics of river ecological status were calculated: (1) Polish Marophyte Index for Rivers, MIR (Szoszkiewicz et al., 2010b); (2) French Indice Biologique Macrophytique en Rivière, IBMR (Haury et al., 2006); (3) British River Macrophyte Nutrient Index, RMNI (Willby et al., 2009). These indices reflect river degradation, especially eutrophication level (concentration of phosphate and total nitrogen).

Benthic macroinvertebrates sampling was carried out together with the macrophyte survey using a hand net with a square frame $(25 \mathrm{~cm} \times 25 \mathrm{~cm}$ and mesh size below $500 \mu \mathrm{m})$ according to the methodology of AQEM (2002) and Bis \& Mikulec (2013), i.e. the Multi-Habitat Sampling (MHS). At each sampling site, a total of 20 replicates (subsamples) was taken proportionally from representative substrates (i.e. mineral and organic substrates that represent not less than 5\% substrate coverage of the stream bottom) in the stretch (sampling surface area $1.25 \mathrm{~m}^{2}$ ) using a hand net. Additionally, benthic macroinvertebrates were collected from the softer bottom sediments among boulders and blocks using a core sampler (diameter $5 \mathrm{~cm}$ ). At each sampling site, 20 samples were collected using a core sampler. All collected material was preserved in $75 \%$ ethanol and then brought back to the laboratory in plastic containers. In the laboratory, the samples were sieved with a $0.23 \mathrm{~mm}$ mesh net and then sorted under a stereoscopic microscope. The benthic macroinvertebrates were counted and identified to the level of family.

Based on the macroinvertebrate survey, the Polish multimetric MMI_PL index (Bis \& Mikulec, 2013) 
was calculated. The values of the multimetric MMI_PL index are based on six key metrics:

1. ASPT (Average Score per Taxon): the value of the BMWP (Biological Monitoring Working Party) divided by the number of BMWP families present in the taxa list. All Oligochaeta were considered as one taxon;

2. $\log _{10}($ Sel_EPTD +1$): \log _{10}$ (sum of individuals of the families Heptageniidae, Ephemeridae, Leptophlebiidae, Brachycentridae, Georidae, Polycentropodidae, Limnephilidae, Odontoceridae, Dolichopodidae, Stratiomyidae, Dixidae, Empididae, Athericidae, Nemouridae +1 );

3. 1-GOLD: 1-(contribution of Gastropoda + Oligochaeta + Diptera);

4. The total number of macroinvertebrate taxa (families) (S);

5. EPT: the total number of families in the Ephemeroptera, Plecoptera and Trichoptera taxa;

6. The Shannon index $\left(H^{\prime}\right): H^{\prime}=-\Sigma\left(p_{\mathrm{i}}\right)\left(\ln p_{\mathrm{i}}\right)$, where $p_{\mathrm{i}}=n_{\mathrm{i}} / N$, the proportion of individuals belonging to family $n_{\mathrm{i}}$, and $N$ is the total number of macroinvertebrate individuals.

Site selection

During the process of site selection, we searched river sites in the area of two ecoregions: Central Highlands (Ecoregion 9) and the Carpathians (Ecoregion 10). More than 150 potential reference sites were checked in the mountain areas (above $500 \mathrm{~m}$ a.s.1.) of Poland and Slovakia. The Central Highlands are formed by the geologically homogeneous (siliceous) Sudeten mountains, representing a uniform abiotic typeSudeten siliceous. The Carpathian Mountains are geologically differentiated, and two main river types are present there: Carpathian calcareous and Carpathian siliceous. A fourth type of rivers, Tatra siliceous, is identified in the Tatra Mountains, which is the highest part of the Carpathians (> $2000 \mathrm{~m}$ a.s.1.).

Out of the initial group of 150 preselected sites, only 60 fulfilled our reference criteria (Fig. 1; 15 Carpathian calcareous, 14 Carpathian siliceous, 18 Sudeten siliceous and 13 Tatra siliceous). These criteria were very strict. The mean concentration of phosphate on selected reference sites was $0.084 \mathrm{mg}$ $\mathrm{PO}_{4}{ }^{3-} 1^{-1}$, nitrate nitrogen was $0.88 \mathrm{mg} \mathrm{N}^{-1}$, ammonium nitrogen $0.11 \mathrm{mg} \mathrm{N}^{-1}$, $\mathrm{BOD}_{5} 1.61 \mathrm{mg}$
$\mathrm{O}_{2} \mathrm{l}^{-1}$ and dissolved oxygen $8.63 \mathrm{mg} \mathrm{O}_{2} \mathrm{l}^{-1}$ as well as indicated high ecological status of the selected sites. The diversity and abundance of natural hydromorphological attributes was also very high (mean HQA = 59.9), whereas the level of hydromorphological modifications was very limited (mean HMS $=1.8$ ). Furthermore, every selected river site was located within a protected nature area, including World Biosphere Reserves, National Parks, Nature Reserves, Landscape Parks, as well as Natura 2000 areas. The distribution of the selected reference sites is presented in Fig. 1.

Advantage of our dataset is its standardisation of methods in terms of strictly standardised field procedure, laboratory work and taxonomical identification. Moreover, all of the surveys were undertaken by a group of experienced surveyors regularly working together and calibrating with each other. In this way, the inter-personal factor, an important source of analytical error in ecological studies, was reduced (Szoszkiewicz et al., 2007). Most other projects analysing reference rivers on a nonlocal scale (more than one ecoregion) have involved a large number of surveyors, who have usually never carried out joint research or may even have used different field protocols (e.g. Baattrup-Pedersen et al., 2008; Birk \& Willby, 2010). Our analyses can therefore be regarded as a unique effort delivering data on mountain reference rivers with a high degree of homogeneity of the biological, hydrochemical and hydromorphological data.

\section{Data analysis}

Data analysis began by testing the distribution of environmental variables using the $\mathrm{W}$-value according to the Shapiro \& Wilk (1965) criteria. To normalise distribution, most of the environmental variables were transformed using the Box-Cox transformation (Box \& Cox, 1964). The significance of differences in environmental variables among types of rivers was tested using one-way ANOVA (StatSoft, 2011) together with a Spjotvoll-Stoline a posteriori test. Brown-Forsyth and Levene's tests were used to assess the equality of variances.

To compare the biological similarity, the mean Jaccard index (Jaccard, 1912) for macrophyte and macroinvertebrate communities in each river type was calculated. In addition, the classification strength was 
Fig. 1 Location of the study area and distribution of the reference river sites. A Sudeten (part of Ecoregion 9), B Western Carpathians (part of Ecoregion 10)

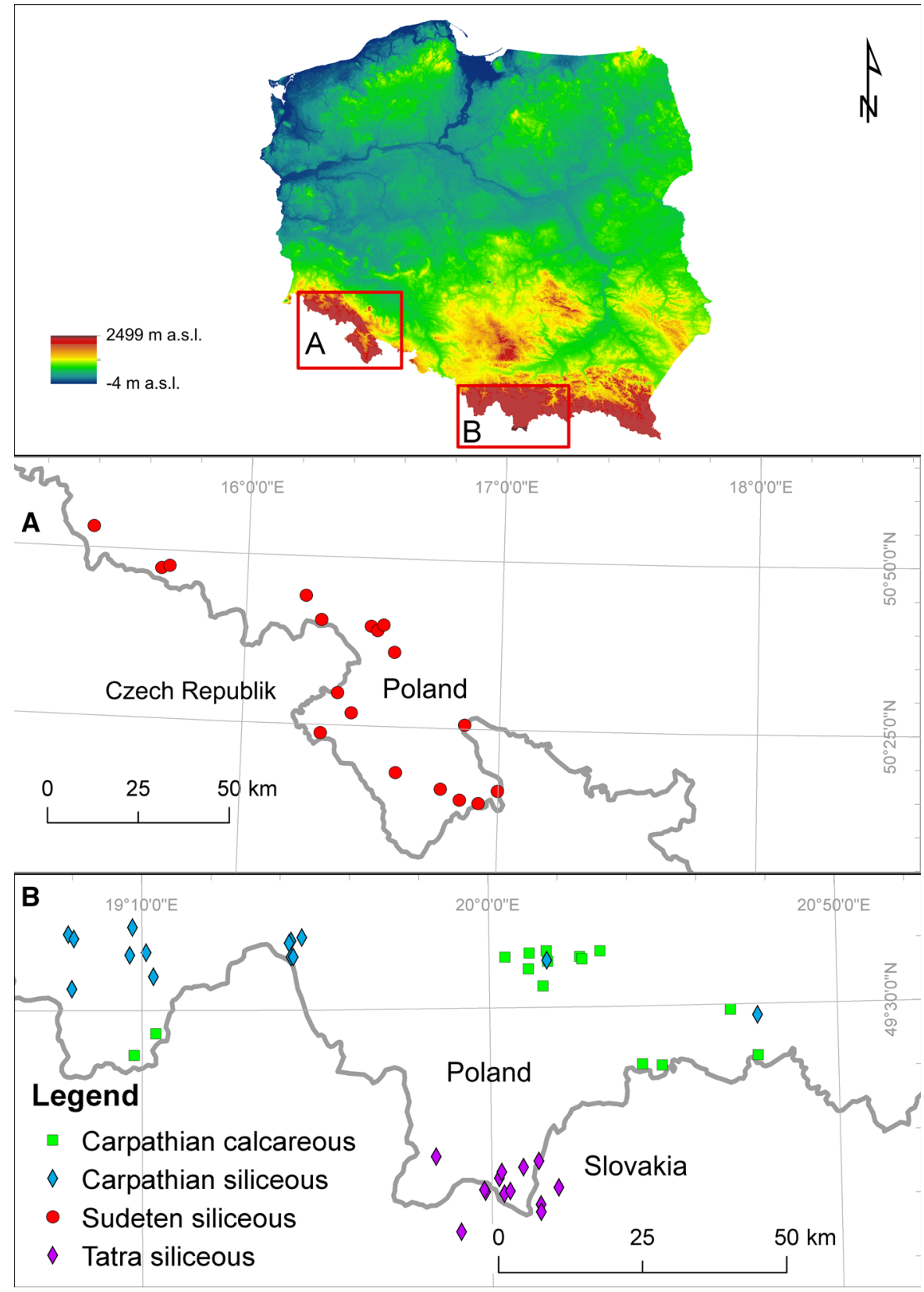

calculated estimating whether the similarity of species composition of the surveyed sites is greater within or between river types (Digby \& Kempton, 1987; Warton et al., 2012; Szoszkiewicz et al., 2016). The significance of differences in biodiversity and biotic indices among river groups was tested using non-parametric Kruskal-Wallis one-way ANOVA witha posteriori test. Ordination analysis for relating the composition of macrophytes and macroinvertebrates to environmental variables was carried out using CANOCO for Windows version 4.56. Preliminary Detrended Correspondence Analysis (DCA) on the biological data revealed that the gradient length was 4.397 standard deviations, indicating that the biological data exhibited unimodal responses to underlying environmental variables; this result justified the use of Gaussian multivariate methods. Therefore, unimodal direct Canonical Correspondence Analysis (CCA) 
with forward variable selection was used to reduce the large set of environmental variables. Rare taxa found at a maximum of three sampling sites were excluded from the analysis. The statistical significance of the relationships between taxa and environmental variables was evaluated using the Monte Carlo permutation test (499 permutations).

\section{Results}

Differentiation of habitat conditions

Mean values of the habitat parameters for the four river types (Carpathian calcareous, Carpathian siliceous, Tatra siliceous and Sudeten siliceous) are presented in Table 1. The largest differences between river types concerned altitude, total hardness and alkalinity $(P<0.001)$. Tatra siliceous rivers differed significantly from all of the other river types in terms of high altitude, slope, higher values of flow dynamics and granulometry indices, low conductivity, alkalinity, total hardness and lower $\mathrm{pH}$. In turn, the hydromorphological quality (HQA, HMS), eutrophication level (phosphate, nitrate and ammonium nitrogen) and organic pollutants (BOD5) were comparable to other river groups $(P>0.05)$. Tatra streams are located in the only Carpathian mountain chain of Alpine type, exceeding the highest other Polish mountain ranges by almost $1000 \mathrm{~m}$ in altitude. The investigated Tatra streams are located at a mean altitude of $1369 \mathrm{~m}$ a.s.l., while rivers in the other groups are at 591-742 m a.s.l.

Diversity of macrophytes and macroinvertebrates against habitat conditions

A relationship between water organisms (macrophytes and macroinvertebrates) and environmental variables was demonstrated by CCA analysis (Fig. 2). The first CCA axis explained $31.9 \%$, and the second axis $26.8 \%$, of the total variance in the relationships between aquatic organisms and environmental variables. This analysis indicated three distinct environmental gradients. The first gradient, related to $\mathrm{pH}$, conductivity, alkalinity and total hardness, may be defined as the geological character of a river, distinguishing between siliceous (right part of Fig. 2) and calcareous rivers (left part of Fig. 2). Taxa particularly

Table 1 Habitat differentiation between river types (mean \pm SD)

\begin{tabular}{|c|c|c|c|c|c|c|}
\hline Parameters & Units & $P$ value & $\begin{array}{l}\text { Carpathian } \\
\text { calcareous } \\
(n=15)\end{array}$ & $\begin{array}{l}\text { Carpathian } \\
\text { siliceous } \\
(n=14)\end{array}$ & $\begin{array}{l}\text { Sudeten } \\
\text { siliceous } \\
(n=18)\end{array}$ & $\begin{array}{l}\text { Tatra siliceous } \\
(n=13)\end{array}$ \\
\hline Altitude & m a.s.1. & $* * *$ & $676 \pm 177$ & $742 \pm 229$ & $592 \pm 118$ & $1369 \pm 272$ \\
\hline Slope & $\%$ & $* *$ & $73.9 \pm 55.1$ & $109.7 \pm 128.4$ & $61.4 \pm 42.9$ & $211.4 \pm 176.3$ \\
\hline Width of riverbed & $\mathrm{m}$ & & $3.8 \pm 1.8$ & $4.7 \pm 2.9$ & $3.6 \pm 2.4$ & $5.6 \pm 4.0$ \\
\hline Depth of riverbed & $\mathrm{m}$ & & $0.24 \pm 0.08$ & $0.23 \pm 0.11$ & $0.30 \pm 0.17$ & $0.31 \pm 0.14$ \\
\hline HQA index & - & & $62.0 \pm 9.6$ & $59.6 \pm 9.7$ & $60.2 \pm 7.1$ & $56.0 \pm 8.9$ \\
\hline HMS index & - & & $1.6 \pm 1.3$ & $1.8 \pm 1.7$ & $2.1 \pm 1.7$ & $1.1 \pm 0.5$ \\
\hline Granulometry index & - & $* *$ & $4.4 \pm 0.7$ & $4.4 \pm 0.5$ & $4.1 \pm 0.7$ & $4.7 \pm 0.5$ \\
\hline Flow dynamics index & - & $* * *$ & $4.2 \pm 0.7$ & $4.1 \pm 0.5$ & $3.8 \pm 0.5$ & $4.8 \pm 0.6$ \\
\hline $\mathrm{pH}$ & $\mathrm{pH}$ scale & $* * *$ & $8.04 \pm 0.25$ & $7.54 \pm 0.45$ & $7.30 \pm 0.48$ & $7.01 \pm 0.81$ \\
\hline Alkalinity & $\mathrm{mg} \mathrm{CaCO}{ }_{3} 1^{-1}$ & $* * *$ & $130.1 \pm 54.6$ & $54.0 \pm 22.2$ & $43.3 \pm 22.6$ & $11.1 \pm 12.8$ \\
\hline Total hardness & $\operatorname{mg~} \mathrm{CaCO}_{3} 1^{-1}$ & $* * *$ & $211.4 \pm 80.9$ & $77.3 \pm 33.3$ & $68.8 \pm 31.2$ & $17.7 \pm 22.4$ \\
\hline Conductivity & $\mu \mathrm{S} \mathrm{cm}-1$ & $* * *$ & $292 \pm 110$ & $137 \pm 71$ & $122 \pm 85$ & $37 \pm 39$ \\
\hline Phosphate & $\mathrm{mg} \mathrm{PO}_{4}{ }^{3-} 1^{-1}$ & & $0.092 \pm 0.050$ & $0.082 \pm 0.047$ & $0.081 \pm 0.032$ & $0.045 \pm 0.038$ \\
\hline Nitrate nitrogen & $\operatorname{mg~N~} 1^{-1}$ & & $0.71 \pm 0.41$ & $0.92 \pm 0.43$ & $0.82 \pm 0.46$ & $0.38 \pm 0.35$ \\
\hline Ammonium nitrogen & $\operatorname{mg~N~} 1^{-1}$ & & $0.10 \pm 0.06$ & $0.16 \pm 0.14$ & $0.10 \pm 0.08$ & $0.04 \pm 0.06$ \\
\hline $\mathrm{BOD}_{5}$ & $\mathrm{mg} \mathrm{O}_{2} 1^{-1}$ & & $1.57 \pm 0.92$ & $1.89 \pm 0.51$ & $1.64 \pm 0.91$ & $1.34 \pm 0.95$ \\
\hline Dissolved oxygen & $\mathrm{mg} \mathrm{O}_{2} 1^{-1}$ & $*$ & $7.29 \pm 1.19$ & $7.83 \pm 1.50$ & $9.86 \pm 1.98$ & $9.35 \pm 1.44$ \\
\hline
\end{tabular}

$\mathrm{df}=102 ; * P<0.01 ; * * P<0.005 ; * * * P<0.001$ 
strongly associated with this gradient include acidophilous bryophyte species: Codriophorus aquaticus (Brid. ex Schrad.) Bedn.-Ochyra \& Ochyra 2003, Codriophorus fascicularis (Schrad. ex Hedw.) Bedn.Ochyra \& Ochyra 2003, Hygrohypnum molle (Hedw.) Loeske 1903, Jungermannia sp. L. 1753, Marsupella emarginata (Ehrh.) Dumort. 1835, Scapania uliginosa (Lindenb.) Dumort. 1835 and Scapania undulata (L.) Dumort. 1835, as well as gastropods from the family Hydrobiidae, mayflies (Siphlonuridae) and caddisflies (Beraeidae, Odontoceridae). The second environmental gradient is related to altitude, channel slope and granulometry. It may be identified as the kinetic energy of flow, making it possible to distinguish Tatra streams (left bottom part of Fig. 2) located at high altitudes, with large riverbed slopes, turbulent flow and coarse-grained material (bedrock, boulders) in comparison with the other rivers. Taxa particularly strongly associated with this gradient include the previously mentioned acidophilous bryophyte species, as well as the stonefly families Capniidae and Perlodidae, and the dipteran families

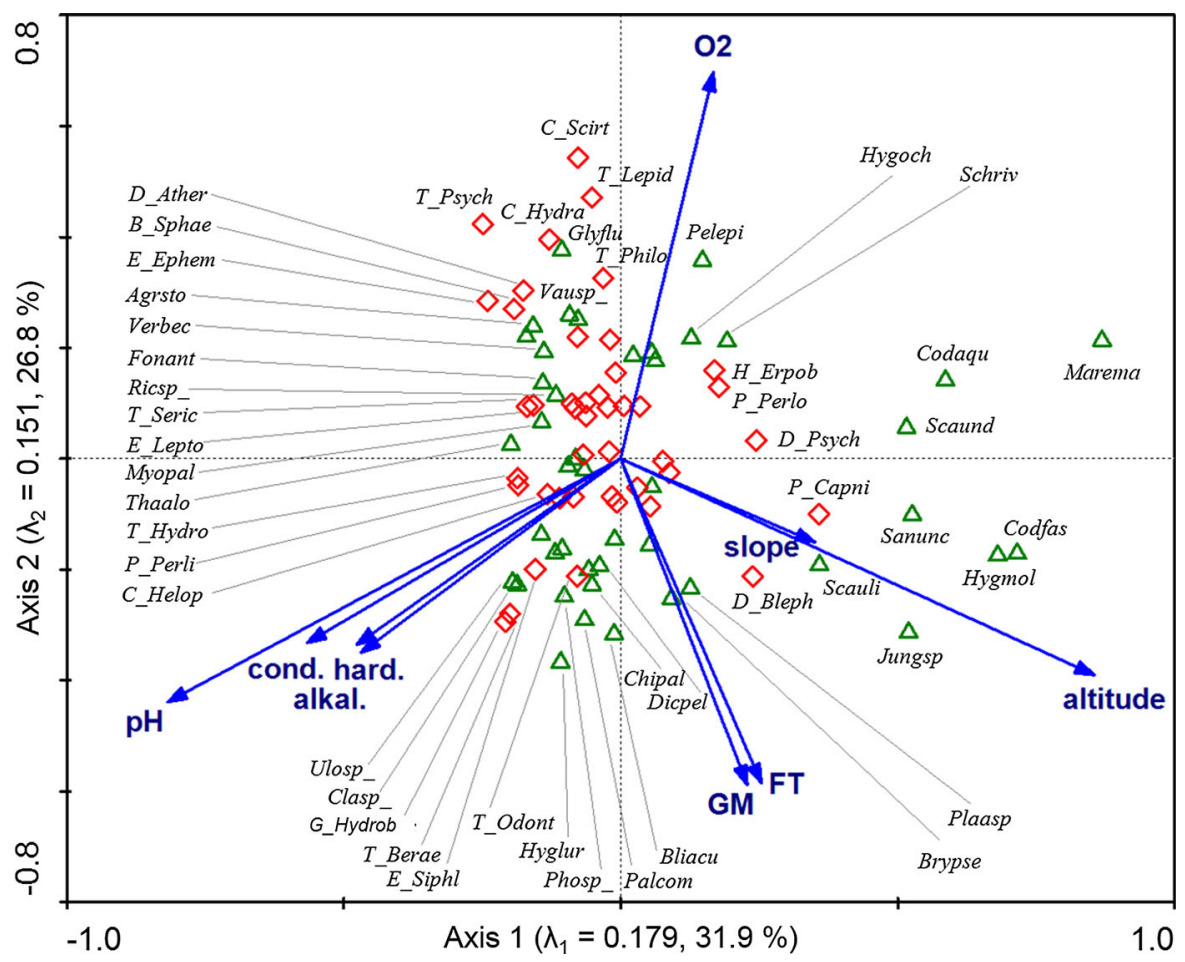

Fig. 2 CCA ordination diagram of macrophytes species, macroinvertebrates families and environmental variables. Full names of environmental variables: alkal.—alkalinity, cond.conductivity, FT-flow dynamics index, GM-granulometry index, hard.-total hardness, $\mathrm{O}_{2}$-dissolved oxygen. Species of macrophytes (green triangles): Agrsto-Agrostis stolonifera, Bliacu-Blindia acuta, Brypse-Bryum pseudotriquetrum, Chipal-Chiloscyphus pallescens, Clasp_-Cladophora sp., Codaqu-Codriophorus aquaticus, Codfas-Codriophorus fascicularis, Dicpel-Dichodontium pellucidum, Fonant-Fontinalis antipyretica, Glyflu-Glyceria fluitans, HyglurHygrohypnum luridum, Hygmol-Hygrohypnum molle, Hygoch-Hygrohypnum ochraceum, Jungsp-Jungermannia sp., Marema-Marsupella emarginata, Myopal-Myosotis palustris, Palcom-Palustriella commutata, Pelepi-Pellia epiphylla, Phosp__Phormidium sp., Plaasp_Plagiochila asplenioides, Ricsp__Riccardia sp., Sanunc_Sanionia uncinata, Scauli-Scapania uliginosa, Scaund-Scapania undulata, Schriv-Schistidium rivulare, Thaalo-Thamnobryum alopecurum, Ulosp_-Ulothrix sp., Vausp_-Vaucheria sp., Verbec-Veronica beccabunga. Families of macroinvertebrates (red diamonds), the first letter is the name order: B_Sphae-Bivalvia -Sphaeriidae, C_Helop-ColeopteraHelophoridae, C_Hydra-Hydraenidae, C_Scirt-Scirtidae, D_Ather-Diptera-Athericidae, D_Bleph-Blephariceridae, D_Psych-Psychodidae, E_Ephem-Ephemeroptera-Ephemerellidae, E_Lepto-Leptophlebiidae, E_Siphl-Siphlonuridae, G_Hydrob-Gastropoda-Hydrobiidae, H_ErpobHirudinea-Erpobdellidae, P_Capni-Plecoptera-Capniidae, P_Perli-Perlidae, P_Perlo-Perlodidae, T_Berae-Trichoptera-Beraeidae, T_Hydro-Hydropsychidae, T_LepidLepidostomatidae, T_Odont-Odontoceridae, T_PhiloPhilopotamidae, T_Psych-Psychomyidae, T_SericSericostomatidae 
Blephariceridae and Psychodidae. The third environmental gradient is related to water oxygenation, being particularly important for macroinvertebrates. The Monte Carlo permutation test showed that most of the analysed environmental variables exhibited statistically significant variation $(P=0.002)$ (Table 2$)$. The greatest effect on variation among macrophytes was found for altitude, $\mathrm{pH}$, conductivity, alkalinity and total hardness, while variation among macroinvertebrates was most affected by water oxygenation, flow dynamics and granulometry of channel material.

Macrophyte and macroinvertebrate similarity between river types

The vegetation of all the mountain reference rivers was dominated by bryophytes (mainly mosses), covering between $70 \%$ (Carpathian calcareous) and $95 \%$ (Tatra siliceous) of the total vegetated surface. The mean values of the Jaccard index for macrophytes in rivers representing the respective types are shown in Table 3. The Carpathian siliceous rivers had the lowest degree of macrophyte similarity (the lowest homogeneity within groups). The most unique macrophyte taxa (giving the highest value of the Jaccard index) were found in the Carpathian calcareous streams. Several species were present exclusively in this type, e.g.: Eucladium verticillatum (With.) Bruch \& Schimp. 1846, Fissidens crassipes Wilson ex Bruch \& Schimp. 1849, Oxyrrhynchium speciosum (Brid.)

Table 2 Results of the Monte Carlo permutation test of the relationship between species composition and nine environmental variables

\begin{tabular}{llll}
\hline Variable & $\lambda_{\mathrm{A}}$ & $F$ & $\lambda_{1}$ \\
\hline Altitude & 0.17 & $4.26^{*}$ & 0.17 \\
$\mathrm{pH}$ & 0.14 & $3.74^{*}$ & 0.16 \\
Slope & 0.09 & $2.55^{*}$ & 0.11 \\
Dissolved oxygen & 0.09 & $2.37^{*}$ & 0.11 \\
Granulometry index & 0.07 & $1.97^{*}$ & 0.10 \\
Alkalinity & 0.06 & $1.68^{*}$ & 0.10 \\
Flow dynamics index & 0.04 & 1.15 & 0.09 \\
Total hardness & 0.04 & 0.93 & 0.09 \\
Conductivity & 0.02 & 0.84 & 0.10 \\
\hline
\end{tabular}

* $P=0.002 ; \lambda_{1}$ is the proportion of variance explained by each single environmental variable, and $\lambda_{\mathrm{A}}$ is the proportion of conditional variance explained by the variable in forward selection
Warnst. 1905 and Plagiothecium nemorale (Mitt.) A. Jaeger 1878. A high degree of species distinctiveness was also found in the Tatra Mountains, due to the number of unique bryophytes such as Andreaea frigida Huebener 1834, Andreaea nivalis Hook. 1811, Anthelia julacea (L.) Dumort. 1835 and Gymnomitrion concinnatum (Lightf.) Corda 1830. Besides the presence of unique species, the Tatra siliceous rivers showed a high abundance of various liverworts, accounting for $45 \%$ of the total vegetation cover. This pattern was also found for Sudeten siliceous rivers, with 35\% of liverwort vegetation. The most abundant Tatra and Sudeten liverworts were Marsupella emarginata, Scapania uliginosa and Scapania undulata.

The abundance of EPT insects (Ephemeroptera, Plecoptera, Trichoptera), which are regarded as indicators of unimpacted and well-oxygenated freshwater ecosystems, was relatively high (up to $60 \%$ of the total invertebrate fauna in the Sudeten siliceous rivers). The most numerous EPT macroinvertebrate families were: Limnephilidae, Baetidae, Nemouridae, Leuctridae, Sericostomatidae and Heptageniidae. A relatively low percentage of EPT taxa (about 20\%) was recorded in the Tatra siliceous streams. The mean values of the Jaccard index (Table 4) showed the lowest degree of macroinvertebrate similarity (the lowest homogeneity within groups) for the Carpathian siliceous rivers. Typical merolimnic organisms such as dipterans of Athericidae and Thaumaleidae and mayflies of Leptophlebiidae were present exclusively in the Carpathian siliceous rivers. The most unique macroinvertebrate taxa (giving the highest value of the Jaccard index) were found in the Carpathian calcareous rivers, including dragonflies from the family Cordulegastridae. A high degree of taxa distinctiveness of macroinvertebrate communities was also found in the Sudeten siliceous rivers, indicating that geographical distance plays an important role in animal species distribution. The pool of exclusive Sudeten taxa consists of the ephemeropteran family Caenidae, the plecopteran family Chloroperlidae and the trichopteran families Lepidostomatidae, Brachycentridae and Leptoceridae. 
Table 3 The Jaccard similarity values between river types based on macrophytes

\begin{tabular}{lllll}
\hline River type & Carpathian calcareous & Carpathian siliceous & Sudeten siliceous & Tatra siliceous \\
\hline Carpathian calcareous & 0.169 & & & \\
Carpathian siliceous & 0.117 & 0.112 & 0.133 \\
Sudeten siliceous & 0.085 & 0.088 & 0.078 & 0.141 \\
Tatra siliceous & 0.092 & 0.088 & \\
\hline
\end{tabular}

Table 4 The Jaccard similarity values between river types based on macroinvertebrates

\begin{tabular}{|c|c|c|c|c|}
\hline River type & Carpathian calcareous & Carpathian siliceous & Sudeten siliceous & Tatra siliceous \\
\hline Carpathian calcareous & 0.425 & & & \\
\hline Carpathian siliceous & 0.363 & 0.345 & & \\
\hline Sudeten siliceous & 0.359 & 0.315 & 0.394 & \\
\hline Tatra siliceous & 0.335 & 0.331 & 0.350 & 0.378 \\
\hline
\end{tabular}

Metrics of ecological status based on macrophytes and macroinvertebrates

The highest values of the MIR, IBMR and RMNI indices were recorded in the Tatra siliceous rivers. These streams differed greatly from all of the other types $(P<0.001)$. The other groups of rivers did not differ significantly from one another (Fig. 3). Outstanding values of macrophyte metrics indicated the very high ecological status of Tatra siliceous rivers, and resulted from the abundance of various bryophyte species, such as Blindia acuta (Hedw.) Bruch \& Schimp. 1846, Codriophorus aquaticus, Codriophorus fascicularis, Hygrohypnum ochraceum (Turner ex Wilson) Loeske 1903, Marsupella emarginata, Scapania uliginosa, Scapania undulata and Sciuro-hypnum plumosum (Hedw.) Ignatov \& Huttunen 2002.

Macroinvertebrates were analysed in terms of the MMI_PL multimetric and its components (Supplementary material). Lowest values of these indices were recorded in the Tatra siliceous rivers (Fig. 4). These streams differed greatly from all of the other types $(P<0.001)$. The variation in MMI_PL between the three river types located at lower altitudes was smaller, although a significant difference was found between Sudeten siliceous and Carpathian siliceous rivers. The values of the ASPT index ranged from 5.85 to 6.25. Analysis of variance confirmed the lack of significant differences in the values of the ASPT between the river types (Fig. 4).

\section{Discussion}

This study showed the roles that geology, geography and hydrology play in structuring river mountain communities. This could be demonstrated evidently because the analyses were based on the results from the reference sites, where the natural gradient was not affected by human activities, such as water pollution and hydromorphological modifications. The increased trophic state leads to degradation of macroinvertebrate and macrophyte communities and the regional differences are usually reflected by differentiated nutrient concentrations associated with both agricultural and urban sources in the watershed (Szoszkiewicz et al., 2006; Zheng et al., 2008). Our previous studies referred to the environmental factors and biological indices applied to benthic macroinvertebrates and macrophytes both at reference and human-impacted streams in two Ecoregions 9 and 10 (Lewin et al., 2014). The results of our previous survey showed that temperature of the water, $\mathrm{pH}$, conductivity, stream gradient, altitude and values of the Habitat Quality Assessment index (HQA) were the parameters most associated (statistically significant) with the distribution of benthic macroinvertebrate taxa and values of the metrics in reference mountain streams of Ecoregions 9 and 10 (Lewin et al., 2013, 2015). Taking into consideration at the same time both the reference and human-impacted streams of the same Ecoregions, only four environmental variables were important, i.e.: $\mathrm{pH}$, 

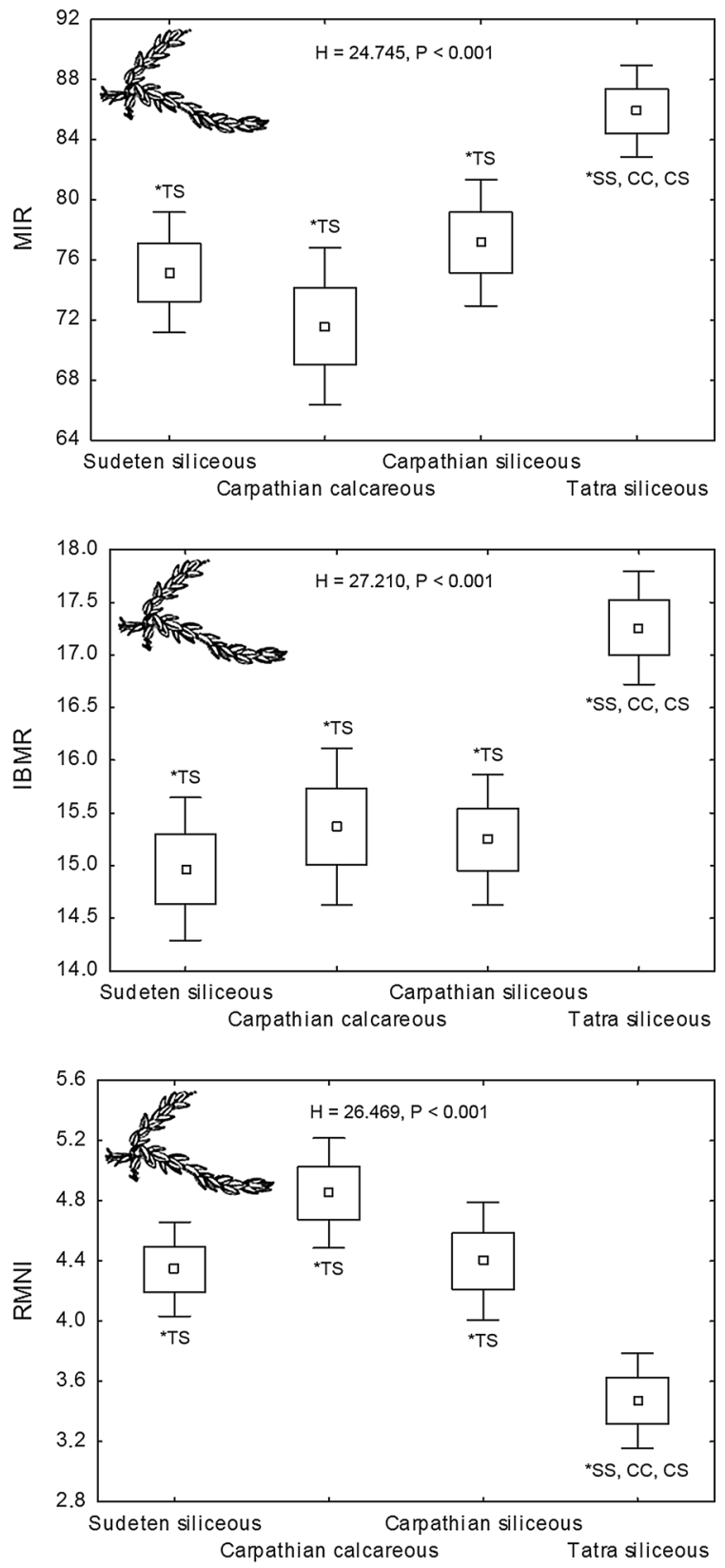

Fig. 3 Variability of macrophyte indices of ecological status among the river groups. The plot indicates mean value \pm standard error $\pm 95 \%$ confidence interval according to the KruskalWallis $H$ test and based on posteriori test $(P<0.05)$, significance marked as asterisk. SS Sudeten siliceous, $C C$ Carpathian calcareous, CS Carpathian siliceous, TS Tatra siliceous

conductivity, stream altitude and values of the HQA index (Lewin et al., 2014). Our results showed lower values of conductivity and $\mathrm{pH}$ in reference siliceous
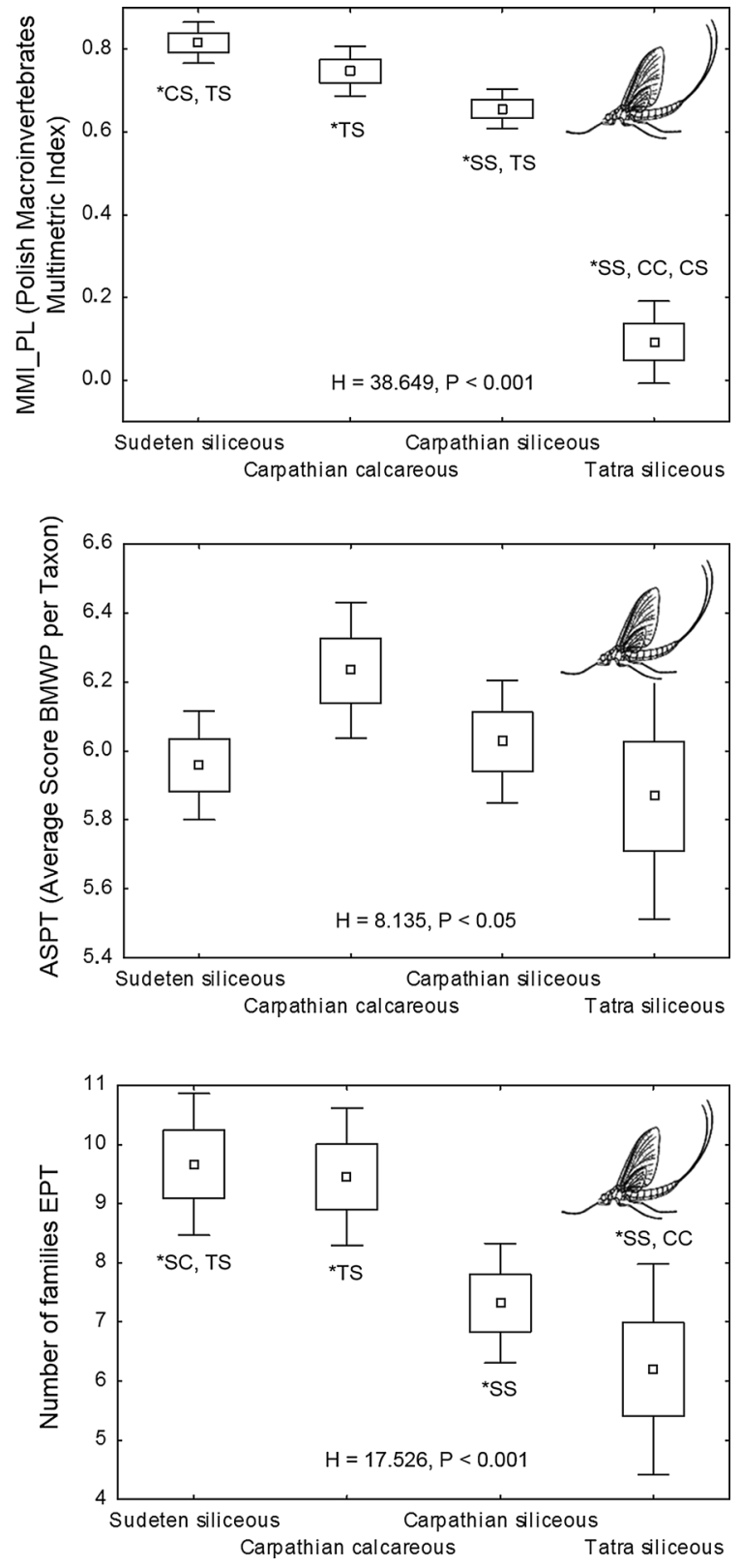

Fig. 4 Variability of macroinvertebrates metrics among the river groups. The plot indicates mean value \pm standard error $\pm 95 \%$ confidence interval according to the KruskalWallis $H$ test and based on posteriori test $(P<0.05)$, significance marked as asterisk. SS Sudeten siliceous, $C C-$ Carpathian calcareous, CS-Carpathian siliceous, TS-Tatra siliceous

streams and higher values in reference calcareous or flysch streams resulting from geology. Relatively high and very high values of conductivity as the results of human activities (pollutions) were recorded in human- 
impacted streams located in the same Ecoregions (Lewin et al., 2014). The HQA index (hydromorphological survey of streams) reflects the natural variation and anthropogenic activities in the river channel and the adjacent area. We obtained higher values of the HQA indices for the reference sites and lower values for the human-impacted ones. To conclude, the same environmental variables reflecting geology, geography or hydrology were the most important (statistically significant) and structuring the mountain stream communities both in the reference and human-impacted sites in these Ecoregions. The importance of geology, geography and hydrology was not displaced by the other factors such as water pollution when affected by human activities (Lewin et al., 2013, 2014, 2015). However, our previous studies showed that severe physical habitat modifications (e.g. lower values of HQA index) or water quality changes in streams and rivers of these two Ecoregions may lead to reductions in aquatic biodiversity that favour alien species over native species. In addition, a few tolerant taxa may dominate and more sensitive organisms may be completely absent.

The analyses performed showed that the gradients of environmental parameters in mountain rivers were very large. The strong direction of variability in environmental data was related to total hardness, conductivity, alkalinity and $\mathrm{pH}$, which could be interpreted as a geological gradient. This factor made it possible to distinguish siliceous rivers flowing through such rocks as granites, gneisses, sandstone and shales, and calcareous rivers flowing through such deposits as chalk, limestone, flysch, marl and shell limestone. A strong variation of bed channel granulometry, water velocity and slope of riverbed, which may be defined as flow kinetic energy. This factor enabled the distinguishing of alpine-like rivers with considerable river slopes, high kinetic energy, turbulent flow and coarse-grained riverbed material (boulders, stones), from submontane rivers with smaller riverbed slopes, low kinetic energy and fine-grained bottom material (cobbles, pebbles). The environmental variation reflected in our database is large enough to analyse sources of biological variation, as water velocity and substrate are considered to be primary factors affecting biological communities in mountain streams (Lorenz et al., 2004; Baattrup-Pedersen et al., 2006; Brabec \& Szoszkiewicz, 2006; Szoszkiewicz et al., 2006; Callanan et al., 2012; Langhammer et al.,
2012; Tremp et al., 2012; Vieira et al., 2014; Ceschin et al., 2015).

The numerous analysed habitat parameters demonstrate the extreme distinctiveness of Tatra siliceous rivers. These rivers are located at the highest altitudes, and their river channels are characterised by the greatest slopes, and related to that, the most dynamic flow and the coarsest-grained riverbed material. Water flowing in such rivers is most depleted in terms of its ion composition, and its $\mathrm{pH}$ is close to neutral (Lewin et al., 2013). Considerable specificity was also found for Carpathian calcareous rivers, which in terms of the water's physical and chemical parameters showed a strong dependence on substrate geology, being characterised by high total hardness, alkalinity, conductivity and $\mathrm{pH}$. This results from the high concentrations of calcium and magnesium bicarbonates in the water. Habitat differences between Carpathian siliceous and Sudeten siliceous rivers were relatively small. However, the spatial factor was significant here, as the Sudeten mountains form a geographically separated mountain range in relation to the other three types, which are located in the Carpathians.

The analyses confirmed that the typological pattern of mountain rivers is supported not only in terms of habitat, but also in the differentiation of biological elements. The four distinguished types of mountain rivers were associated with taxonomic diversification in both investigated groups of organisms. The taxa variation is more distinct among macroinvertebrates communities than those of macrophytes, as indicated by the higher values of the Jaccard index and variation in diversity indexes. Both macrophytes and macrozoobenthos were also surveyed by Pinto et al. (2006) at high ecological quality sites (with at least good ecological status) sampled across Europe, and in that study also many similarities were found in the response of invertebrates and macrophytes to habitat conditions in mountain rivers. A study by Hughes et al. (2009) also showed under natural conditions similar response of these groups of organisms to habitat factors in rivers. A study on macroinvertebrate communities by Callanan et al. (2012) showed that geology and its co-variables, including conductivity and $\mathrm{pH}$, play a considerable role in defining the distribution of this group of organisms. On the other hand, exclusively macrophyte-based studies also confirm numerous properties of plants potentially 
indicating response to a typological factor (BaattrupPetersen et al., 2006, 2008; Jusik et al., 2015). The detected parallel between macroinvertebrates' and macrophytes' reaction to habitat contrition proves that both organism groups can be applied in river monitoring in the case of mountain streams. This is very advantageous, since monitoring based on a single organism group is more risky and less resistant to various sources of distortion than biomonitoring involving two (or more) organism groups (Marzin et al., 2012).

The biological variation, in combination with abiotic habitat conditions, reflects the existence of four mountain and upland river types (Carpathian calcareous, Carpathian siliceous, Tatra siliceous and Sudeten siliceous). The taxonomical differentiation between Carpathian siliceous and Sudeten siliceous rivers reveals the impact of geographical isolation between two ecoregions (9-Central Highlands, 10The Carpathians) on biological diversification.

The most unique pool of both macrophyte and macroinvertebrate taxa (the highest values of the Jaccard index, specific taxa) was found in the Carpathian calcareous streams, indicating the principal role of the geological factor in biological differentiation. The Carpathian calcareous river flora and fauna were most different from those of the Sudeten siliceous rivers, due to geographical remoteness as well as differences in geological substrate. Carpathian siliceous rivers have the lowest degree of both macrophyte and invertebrate similarity, which is not surprising, in view of the geographical proximity to other Carpathian types and the similarity of geological substrate with the Sudeten region. A high degree of taxa distinctiveness of macroinvertebrate communities was exhibited also at the Sudeten siliceous streams. This demonstrates that geographical distance plays an important role in animal species distribution. The distinctiveness of Sudeten macroinvertebrates is confirmed by the Jaccard index as well as by the exceptionally high diversity (number of families and Shannon index). On the other hand, the flora of Sudeten siliceous streams was not as different from other regions as it was in case of the macroinvertebrates.

A high degree of plant species distinctiveness was identified for the Tatra Mountains, where an exceptionally high portion of liverworts and the presence of numerous exclusive bryophyte species was found.
These groups of plants indicate a high ecological quality, which was reflected by the MIR index. On the other hand, Tatra macroinvertebrate communities, though also quite distinct, indicated low values of ecological status (multimetric MMI_PL). The lowest values of these macroinvertebrate indices were recorded at unimpacted sites situated above $1500 \mathrm{~m}$ a.s.l. Analysis showed that the MMI_PL values of pristine Tatra streams are so low due to limited diversity (a small number of macroinvertebrate families and low values of the Shannon index) and $\log _{10}($ EPTD +1$)$ values (Lewin et al., 2014). A similar pattern was presented by Šporka et al. (2009), who showed that macroinvertebrate metrics fall above $800 \mathrm{~m}$ a.s.l. in both unimpacted and impacted small streams of the Carpathian Mountains (Ecoregion 10). According to Valle et al. (2015), some macroinvertebrate metrics (e.g. EPT) may still properly reflect the quality of the waters in streams situated at 1200-1300 $\mathrm{m}$ a.s.l. All of these findings show that the specific conditions of high mountains strongly influence the development of distinctive communities of both plants and animals, and in consequence, the macroinvertebrate diversity metrics alone are not applicable for mountain stream monitoring situated above $1500 \mathrm{~m}$ a.s.l. On the other hand, metrics based on aquatic plants are resistant to the altitude effect, and all macrophyte indices are applicable in high mountains.

The specific response of macroinvertebrate stream communities to high altitude, which distorts monitoring methods, is due to the specific reaction of various taxa beyond their range of tolerance (Jacobsen et al., 2003). The critical value (threshold) at which rapid response of macroinvertebrate communities occurs as a result of alternation in the environmental gradient is interpreted as a change point (Marzin et al., 2012; Sundermann et al., 2015). Thresholds of physical and chemical parameters as well as of hydromorphological features and catchment or riparian land use categories have been identified (Dahm et al., 2013). For example, the change point of conductivity for the ASPT index ranges between 160 and $1260 \mu \mathrm{S} \mathrm{cm}^{-1}$ in mountain streams, whereas the change point of forest as a category of riparian land use ranges between 0 and 10\% (Dahm et al., 2013). The relatively low number of macroinvertebrate taxa or limited stability of macroinvertebrate communities in pristine high-altitude mountain streams may be attributed to harsh 
environmental conditions, such as high spring runoff following a heavy snow-pack in the winter or surface transport of sediments (Milner et al., 2016). The area of our surveys also included pristine high-altitude siliceous streams of a World Biosphere Reserve-the Tatra UNESCO Biosphere Reserve-with distinct vegetation zones that are dependent on the habitat and climatic conditions. Snow cover on the highest peaks can last for 200 days a year, and some snowfields are present throughout the year. In the alpine zone, between 1500 and $1800 \mathrm{~m}$ a.s.l., dwarf pine (Pinus mugo) vegetation is predominant rather than forests, and the landscape is largely rock and scree. Thus, in our survey, the distinctive pattern of macroinvertebrates distribution in the Tatra siliceous streams was reflected by relatively low values of biotic indices, which was not the result of stream degradation. Our results show that high-altitude sites require a different approach in assessing their ecological status than in the case of rivers located in the lower mountains and the lowlands. Macroinvertebrate monitoring in the high mountains requires reorganisation of the border values between quality classes (Lewin et al., 2014). If the modified system still fails to perform correctly, mountain monitoring must be limited to other groups of organisms, for instance macrophytes and diatoms (Brabec \& Szoszkiewicz, 2006; Hering et al., 2006).

We found that the spatial factor (difference between ecoregions) causes diversification mostly among macroinvertebrates and plays a limited role in the development of macrophyte communities, since the plant species distributions were not limited by the borders of ecoregions. A very similar pattern was found by Mykrä et al. (2009) in boreal reference streams, where macroinvertebrates were well discriminated by geographical location (as well as stream size, and percentage of the catchment area covered by peatland), whereas only alkalinity discriminated the macrophyte groups. Geographical location was also identified as one of the major factors influencing macroinvertebrate communities, which should be taken into consideration in the assessment of river typology based on biotic elements. Some differentiation of vegetation between adjacent physiographic units was detected by Wiegleb et al. (2015) in northwest Germany, but on the other hand, the limited role of ecoregional criteria in explaining the macrophyte distribution has been revealed by other studies, for instance Jusik et al. (2015) in Poland, Vieira et al.
(2016) in Mediterranean Europe as well as BaattrupPetersen et al. (2006, 2008), who have undertaken relevant multivariate analyses of the macrophyte sites recorded across several European ecoregions. In the case of macroinvertebrate distribution patterns, the apparent impact of a geographical factor was detected in headwater streams by Astorga et al. (2014). Our results, as well as numerous other studies, indicate that the spatial factor is particularly important for invertebrate discrimination, while in the case of aquatic plants geographical isolation plays more limited role.

\section{Conclusions}

The river typological system was confirmed on the basis of two biological elements (macrophytes and macroinvertebrates) as well as abiotic factors, including geologically derived physical and chemical parameters of the water, the spatial factor, altitude and hydromorphology. The spatial factor (geographical location) causes diversification chiefly among macroinvertebrates, and plays a limited role in the development of macrophyte communities. Macrophyte communities are not constrained by the spatial factor, since the species distribution is not limited by the borders of ecoregions.

Macrophyte in mountain rivers in reference condition react most distinctly to altitude, $\mathrm{pH}$, conductivity, alkalinity and total hardness, whereas macroinvertebrates depends primarily on dissolved oxygen, flow dynamics and granulometry of channel material. Standard methods of ecological status assessment can be applied in the majority of mountain river types. Extreme mountain conditions can sometimes distort bioindicative reaction, as was detected in the case of macroinvertebrates in the highest located mountain sites (above $1500 \mathrm{~m}$ a.s.1.). A different approach to ecological status assessment must be developed for these streams in the future, but biological monitoring can currently rely on macrophytes. Consideration of two groups of organisms enables more comprehensive and reliable monitoring than assessment based on a single group of organisms, especially where the standard bioindicative practices can be distorted by extreme local conditions.

Acknowledgements This work was supported by the National Science Centre Poland based on decision no. DEC-2012/04/S/ 
NZ8/00195 and N N305 226033. We wish to thank the following specialists for their help with the survey work and scientific advice: Marcin Przesmycki of the Inspection of Environmental Protection in Wałbrzych (Poland), Eva Bulánková of Comenius University in Bratislava (Slovakia), Paul Raven of the Freshwater Biological Association (UK), and Hugh Dawson and Peter Scarlett, both of the Centre for Ecology and Hydrology (UK). Special thanks to Nigel Holmes of Alconbury Consulting (UK), who checked the identity of many of the species found during this study.

Open Access This article is distributed under the terms of the Creative Commons Attribution 4.0 International License (http:// creativecommons.org/licenses/by/4.0/), which permits unrestricted use, distribution, and reproduction in any medium, provided you give appropriate credit to the original author(s) and the source, provide a link to the Creative Commons license, and indicate if changes were made.

\section{References}

Antheunisse, A. M., R. Loeb, L. P. M. Lamers \& J. T. A. Verhoeven, 2006. Regional differences in nutrient limitation in floodplains of selected European rivers: implications for rehabilitation of characteristic floodplain vegetation. River Research \& Applications 22: 1039-1055.

Astorga, A., R. Death, F. Death, R. Paavola, M. Chakraborty \& T. Muotka, 2014. Habitat heterogeneity drives the geographical distribution of beta diversity: the case of New Zealand stream invertebrates. Ecology and Evolution 4(13): 2693-2702.

AQEM Consortium, 2002. Manual for the application of the AQEM system. A comprehensive method to assess European streams using benthic macroinvertebrates, developed for the purpose of the Water Framework Directive. Version 1.0. www.aqem.de.

Baattrup-Pedersen, A., K. Szoszkiewicz, R. Nijboer, M. O’Hare \& T. Ferreira, 2006. Macrophyte communities in unimpacted European streams: variability in assemblage patterns, abundance and diversity. Hydrobiologia 566: 179-196.

Baattrup-Pedersen, A., G. Springe, T. Riis, S. E. Larsen, K. Sand-Jensen \& L. M. Kjellerup Larsen, 2008. The search for reference conditions for stream vegetation in northern Europe. Freshwater Biology 53: 1890-1901.

Bis, B. \& A. Mikulec, 2013. Przewodnik do oceny stanu ekologicznego rzek na podstawie makrobezkręgowców bentosowych. Biblioteka Monitoringu Środowiska, Warszawa. (in Polish).

Birk, S. \& N. Willby, 2010. Towards harmonization of ecological quality classification: establishing common grounds in European macrophyte assessment for rivers. Hydrobiologia 652(1): 149-163.

Błachuta, J., K. Szoszkiewicz, D. Gebler \& S. C. Schneider, 2014. How do environmental parameters relate to macroinvertebrate metrics-prospects for river water quality assessment. Polish Journal of Ecology 62(1): 111-122.
Box, G. E. P. \& D. R. Cox, 1964. An analysis of transformations. Journal of the Royal Statistical Society 26(2): 211-252.

Brabec, K. \& K. Szoszkiewicz, 2006. Macrophytes and diatoms-major results and conclusions from the STAR project. Hydrobiologia 566: 175-178.

Callanan, M., J. R. Baars \& M. Kelly-Quinn, 2012. A typological classification of headwater streams in Ireland. Biology and Environment 112(3): 243-255.

Ceschin, S., M. R. Minciardi, C. D. Spada \& S. Abati, 2015. Bryophytes of alpine and apennine mountain streams: floristic features and ecological notes. Cryptogamie, Bryologie 36(3): 267-283.

Dahm, V., D. Hering, D. Nemitz, W. Graf, A. Schmidt-Kloiber, P. Leitner, A. Melcher \& C. K. Feld, 2013. Effects of physico-chemistry, land use and hydromorphology on three riverine organism groups: a comparative analysis with monitoring data from Germany and Austria. Hydrobiologia 704: 389-415.

Demars, B. O. L., J. M. Potts, M. Trémolières, G. Thiébaut, N. Gougelin \& V. Nordmann, 2012. River macrophyte indices: not the Holy Grail! Freshwater Biology 57: 1745-1759.

Digby, P. G. N. \& R. A. Kempton, 1987. Multivariate Analysis of Ecological Communities. Chapman and Hall, London, New York.

Dynesius, M. \& C. Nilsson, 1994. Fragmentation and flow regulation of river systems in the northern third of the world. Science 266(5186): 753-762.

European Commission, 2000. Directive 2000/60/EC of the European Parliament and of the Council-Establishing a framework for Community action in the field of water policy, Brussels, Belgium, 23 October 2000.

Gerth, W. J., A. T. Herlihy \& J. C. Sifneos, 2013. Large-scale macroinvertebrate assemblage patterns from least-disturbed wadeable stream sites across the 48 contiguous US states. Knowledge and Management of Aquatic Ecosystems 408: 02.

Haury, J., M.-C. Peltre, M. Trémolières, J. Barbe, G. Thiébaut, I. Bernez, H. Daniel, P. Chatenet, G. Haan-Archipof, S. Muller, A. Dutartre, C. Laplace-Treyture, A. Cazaubon \& E. Lambert-Servien, 2006. A new method to assess water trophy and organic pollution-the Macrophyte Biological Index for Rivers (IBMR): its application to different types of river and pollution. Hydrobiologia 570: 153-158.

Hering, D., R. K. Johnson, S. Kramm, S. Schmutz, K. Szoszkiewicz \& P. F. M. Verdonschot, 2006. Assessment of European streams with diatoms, macrophytes, macroinvertebrates and fish: a comparative metric-based analysis of organism response to stress. Freshwater Biology 51: 1757-1785.

Hughes, S. J., J. M. Santos, M. T. Ferreira, R. Caraça \& A. Mendes, 2009. Ecological assessment of an intermittent Mediterranean river using community structure and function: evaluating the role of different organism groups. Freshwater Biology 54: 2383-2400.

Jaccard, P., 1912. The distribution of the flora in the alpine zone. New Phytol. 11(2): 37-50.

Jacobsen, D., S. Rostgaard \& J. J. Vásconez, 2003. Are macroinvertebrates in high altitude streams affected by oxygen deficiency? Freshwater Biology 48: 2025-2032. 
Johnson, R. K. \& D. Hering, 2009. Response of taxonomic groups in streams to gradients in resource and habitat characteristics. Journal of Applied Ecology 46(1): 175-186.

Jusik, S., K. Szoszkiewicz, J. M. Kupiec, I. Lewin \& A. Samecka-Cymerman, 2015. Development of comprehensive river typology based on macrophytes in the mountainlowland gradient of different Central European ecoregions. Hydrobiologia 745: 241-262.

Kosnicki, E., S. A. Sefick, M. H. Paller, M. S. Jarrell, B. A. Prusha, S. C. Sterrett, T. D. Tuberville \& J. W. Feminella, 2014. Defining the reference condition for wadeable streams in the Sand Hills subdivision of the Southeastern Plains Ecoregion, USA. Environmental Management 54: 494-504.

Krno, I., F. Šporka, Z. Pastuchová, T. Derka, Z. ČiamporováZatovičová, E. Bulánková, L. Hamerlík \& D. Illéšová, 2007. Assessment of the ecological status of streams in two Carpathian subregions. International Review of Hydrobiology 92(4-5): 564-581.

Lainé, M., S. Morin \& J. Tison-Rosebery, 2014. A multicompartment approach-Diatoms, macrophytes, benthic macroinvertebrates and fish-To assess the impact of toxic industrial releases on a small French river. PLoS ONE. https://doi.org/10.1371/journal.pone.0102358.

Langhammer, J., F. Hartvich, D. Mattas, S. Rödlová \& A. Zborill, 2012. The variability of surface water quality indicators in relation to watercourse typology, Czech Republic. Environmental Monitoring and Assessment 184: 3983-3999.

Lewin, I., I. Czerniawska-Kusza, K. Szoszkiewicz, A. E. Ławniczak \& S. Jusik, 2013. Biological indices applied to the benthic macroinvertebrates at reference conditions of mountain streams in two ecoregions (Poland, the Slovak Republic). Hydrobiologia 709(1): 183-200.

Lewin, I., S. Jusik, K. Szoszkiewicz, I. Czerniawska-Kusza \& A. E. Ławniczak, 2014. Application of the new multimetric MMI_PL index for biological water quality assessment in reference and human-impacted streams (Poland, the Slovak Republic). Limnologica 49: 42-51.

Lewin, I., K. Szoszkiewicz, S. Jusik \& A. E. Ławniczak, 2015. Influence of selected environmental factors on macroinvertebrates in mountain streams. Open Life Sciences 10: 99-111.

Lorenz, A., C. K. Feld \& D. Hering, 2004. Typology of streams in Germany based on benthic invertebrates: ecoregions, zonation, geology and substrate. Limnologica 34: 379-389.

Malmqvist, B. \& S. Rundle, 2002. Threats to the running water ecosystems of the world. Environmental Conservation 29: 134-153.

Manfrin, A., S. Larsen, L. Traversetti, G. Pace \& M. Scalici, 2013. Longitudinal variation of macroinvertebrate communities in a Mediterranean river subjected to multiple anthropogenic stressors. International Review of Hydrobiology 98(3): 155-164.

Mao, F. \& K. Richards, 2012. Irreversible water quality and the concept of the reference condition. Area 44(4): 423-431.

Marzin, A., V. Archaimbault, J. Belliard, C. Chauvin, F. Delmas \& D. Pont, 2012. Ecological assessment of running waters: do macrophytes, macroinvertebrates, diatoms and fish show similar responses to human pressures? Ecological Indicators 23: 56-65.

Mazur, R., T. Kałuża, J. Chmist, N. Walczak, I. Laks \& P. Strzeliński, 2016. Influence of deposition of fine plant debris in river floodplain shrubs on flood flow conditionsThe Warta River case study. Physics and Chemistry of the Earth, Parts A/B/C 94: 106-113.

Milner, A. M., A. Woodward, J. E. Freilich, R. W. Black \& V. H. Resh, 2016. Detecting significant change in stream benthic macroinvertebrate communities in wilderness areas. Ecological Indicators 60: 524-537.

Moss, B., 2008. The Water Framework Directive: total environment or political compromise? Science of the Total Environment 400: 32-41.

Mykrä, H., J. Aroviita, H. Hämäläinen, S. M. Karjalainen, M. Visuri, J. Riihimäki, J. Miettinen \& K. M. Vuori, 2009. Utility of a single a priori river typology for reference conditions of boreal macroinvertebrates and diatoms. Fundamental and applied limnology. Archiv für Hydrobiologie 175(4): 269-280.

Nõges, P., W. van de Bund, A. C. Cardoso, A. G. Solimini \& A. S. Heiskanen, 2009. Assessment of the ecological status of European surface waters: a work in progress. Hydrobiologia 633: 197-211.

Pinto, P., M. Morais, M. Ilheu \& L. Sandin, 2006. Relationships among biological elements (macrophytes, macroinvertebrates and ichthiofauna) for different core river types across Europe at two different spatial scales. Hydrobiologia 566: 75-90.

Pond, G. J., 2012. Biodiversity loss in Appalachian headwater streams (Kentucky, USA): plecoptera and Trichoptera communities. Hydrobiologia 679: 97-117.

Raven, P. J., N. T. H. Holmes, F. H. Dawson, P. J. A. Fox, M. Everard, I. R. Fozzard \& K. J. Rouen, 1998. River Habitat Quality the physical character of rivers and streams in the UK and Isle of Man. Environment Agency. Stirling, Environment and Heritage Service, Belfast: 1-96.

Shapiro, S. S. \& M. B. Wilk, 1965. An analysis of variance test for normality (complete samples). Biometrika 52(3-4): 591-611.

Šporka, F., Z. Pastuchová, L. Hamerlík, M. Dobiašová \& P. Beracko, 2009. Assessment of running waters (Slovakia) using benthic macroinvertebrates-derivation of ecological quality classes with respect to altitudinal gradients. Biologia 64(6): 1196-1205.

StatSoft, Inc., 2011. STATISTICA (data analysis software system), version 9.1, www.statsoft.com.

Stoddard, J. L., D. P. Larsen, C. P. Hawkins, R. K. Johnson \& R. H. Norris, 2006. Setting expectations for the ecological condition of streams: the concept of reference condition. Ecological Applications 16(4): 1267-1276.

Sundermann, A., M. Leps, S. Leisner \& P. Haase, 2015. Taxonspecific physico-chemical change points for stream benthic invertebrates. Ecological Indicators 57: 314-323.

Szoszkiewicz, K., T. Ferreira, T. Korte, A. Baattrup-Pedersen, J. Davy-Bowker \& M. O'Hare, 2006. European river plant communities: the importance of organic pollution and the usefulness of existing macrophyte metrics. Hydrobiologia 566: 211-234.

Szoszkiewicz, K., S. Jusik, T. Zgoła, M. Czechowska \& B. Hryc, 2007. Uncertainty of macrophyte-based monitoring for 
different types of lowland rivers. Belg. J. Bot. 140(1): $7-16$.

Szoszkiewicz, K., S. Jusik, A. E. Ławniczak \& T. Zgoła, 2010a. Macrophyte development in unimpacted lowland rivers in Poland. Hydrobiologia 656: 117-131.

Szoszkiewicz, K., J. Zbierska, S. Jusik \& T. Zgoła, 2010 b. Metodyka badań terenowych makrofitów na potrzeby rutynowego monitoringu rzek [Macrophyte survey manual for the purpose of river monitoring]. Bogucki Wydawnictwo Naukowe, Poznan (in Polish).

Szoszkiewicz, K., A. Budka, K. Pietruczuk, D. Kayzer \& D. Gebler, 2016. Is the Macrophyte Diversification along the Trophic Gradient Distinct Enough for River Monitoring? Environmental Monitoring and Assessment 189(1): 4.

Thiébaut, G., G. Tixier, F. Guérold \& S. Muller, 2006. Comparison of different biological indices for the assessment of river quality: application to the upper river Moselle (France). Hydrobiologia 570(1): 159-164.

Traversetti, L., M. Scalici, V. Ginepri, A. Manfrin \& S. Ceschin, 2014. Concordance between macrophytes and macroinvertebrates in a Mediterranean river of central Apennine region. Journal of Environmental Biology 35: 497-503.

Traversetti, L., S. Ceschin, A. Manfrin \& M. Scalici, 2015. Cooccurrence between macrophytes and macroinvertebrates: towards a new approach for the running waters quality evaluation? Journal of Limnology 74(1): 133-142.

Tremp, H., D. Kampmann \& R. Schulz, 2012. Factors shaping submerged bryophyte communities: a conceptual model for small mountain streams in Germany. Limnologica 2: 242-250.

Valle Jr., R. F., S. G. P. Varandas, A. L. Fernando, F. A. L. Pacheco, V. R. Pereira, C. F. Santos, M. V. Rui, R. M. V. Cortes \& L. F. Sanches Fernandes, 2015. Impacts of land use conflicts on riverine ecosystems. Land Use Policy 43: 48-62.

Vieira, C., F. C. Aguiar \& M. T. Ferreira, 2014. The relevance of bryophytes in the macrophyte-based reference conditions in Portuguese rivers. Hydrobiologia 734(1): 245-264.
Vieira, C., F. C. Aguiar, A. P. Portela, J. Monteiro, P. J. Raven, N. T. H. Holmes, J. Cambra, N. Flor-Arnau, C. Chauvin, S. Loriot, T. Feret, G. Dörflinger, M. Germ, U. Kuhar, E. Papastergiadou, P. Manolaki, M. R. Minciardi, A. Munné, G. Urbanič \& M. T. Ferreira, 2016. Bryophyte communities of Mediterranean Europe: a first approach to model their potential distribution in highly seasonal rivers. Hydrobiologia. https://doi.org/10.1007/s10750-016-27435.

Warton, D. I., T. W. Wright \& Y. Wang, 2012. Distance-based multivariate analyses confound location and dispersion effects. Methods in Ecology and Evolution 3: 89-101.

Wiegleb, G., W. Herr, B. Zander, U. Bröring, H. Brux \& K. van de Weyer, 2015. Natural variation of macrophyte vegetation of lowland streams at the regional level. Limnologica 51: 53-62.

Willby, N., J. A. Pitt \& G. Phillips, 2009. The Ecological Classification of UK Rivers Using Aquatic Macrophytes. UK Environment Agency Science Reports. Project SC010080/SR1. Environmental Agency, Bristol.

Wyżga, B., J. Zawiejska, A. Radecki-Pawlik \& H. Hajdukiewicz, 2012. Environmental change, hydromorphological reference conditions and the restoration of Polish Carpathian rivers. Earth Surface Processes and Landforms 37(11): 1213-1226.

Zawilińska, B. \& M. Mika, 2013. National parks and local development in Poland: a municipal perspective. Human Geographies-Journal of Studies and Research in Human Geography 7(1): 43-52.

Zheng, L., J. Gerritsen, J. Beckman, J. Ludwig \& S. Wilkes, 2008. Land use, geology, enrichment, and stream biota in the Eastern Ridge and Valley ecoregion: implications for nutrient criteria development. Journal of the American Water Resources Association 44(6): 1521-1536. 